\title{
Yalova merkez ilçesi kıyı bandı örneğinde kentsel peyzaj planlama odaklı mekânsal gelişim stratejilerinin belirlenmesi
}

Determination of spatial development strategies focused on urban landscape planning in the example of the coastal strip of the central district of Yalova

\author{
Ibrahim Emir KEÇECi ${ }^{1}$ iD, Tuğba KiPER ${ }^{1 \mathscr{C}}$ (D) , Murat ÖZYAVUZ1 ${ }^{1 D}$ \\ ${ }^{1}$ Tekirdağ Namık Kemal Üniversitesi, Güzel Sanatlar Tasarım ve Mimarlık Fakültesi, Peyzaj Mimarlığı Bölümü, Tekirdağ.
}

MAKALE BILGISI / ARTICLE INFO

\section{Makale tarihçesi / Articlehistory: \\ DOI: $10.37908 / \mathrm{mkutbd} .806148$ \\ Geliş tarihi /Received:05.10.2020 \\ Kabul tarihi/Accepted:24.11.2020}

\section{Keywords:}

Urban landscape planning, spatial planning, coastal area planning, Yalova.

\footnotetext{
Correspondingauthor: Tuğba KIPER

$\bowtie:$ tkiper@nku.edu.tr
}

\author{
ÖZET / A B S T R A C T
}

\begin{abstract}
Aims: It is aimed to develop spatial development strategies focused on landscape planning in order to create a social, cultura land environmental focus by building the relationship of the coastal strip of Yalova central district with the city and increasing the visua land physical quality.

Methods and Results: The method used in the study has been developed under five main headings including defining the purpose and scope of the study area, determining the landscape values of Yalova, the fiction between the city center and the coast line, SWOT analysis and specifying spatial development strategies on the basis of landscape planning-oriented goals and sub-goals.

Conclusions: It was determined within the scope of the findings obtained within the framework of the method that the coastal area was isolated from the city and the relation ship between the city and the coast was weak. In this context, targets and strategies have been developed to integrate the coastline with the city.

Significance and Impact of the Study: By considering the coastal line of the central district of Yalova in a holistic manner, goals were set tos olve the problems by evaluating and revealing its potential, and accordingly, spatialbased development strategies in the central district coast line were proposed. These strategies have been aimed at providing spatial gains that strengthen the image of Yalova's coastal city, increasethe life quality of the city, emphasize that the coastal zones hould be inrelation to the whole city, and shouldadd social, cultural, economic and natural value to the city.
\end{abstract}

\footnotetext{
Atıf / Citation: Keçeci E, Kiper T, Özyavuz M (2021) Yalova merkez ilçesi kıyı bandı örneğinde kentsel peyzaj planlama odaklı mekânsal gelişim stratejilerinin belirlenmesi. MKU. Tar. Bil. Derg. 26(1) : 142-154. DOI: $10.37908 /$ mkutbd. 806148
}

\section{Giriş}

Endüstrileşme kaynaklı, kırdan kente doğru yayılım gösteren nüfus yoğunluğundaki artışın getirdiği süreç ile birlikte; mekânsal, çevresel, ekonomik ve sosyal alanlarda birtakım değişimler yaşanmıştır. Bu değişimlerin sonucu olarak; kentsel gelişme eğilimleri paralelinde; tarım, alanları, sulak alanlar, afet riski taşıyan bazı alanların (dere yatakları, jeolojik yönden sakıncalı olan alanlar, heyelan riski taşıyan bölgeler vb.) yerleşime açılmasıyla, yoğun kullanımlı çok şeritli araç odaklı yolların yer aldığı ulaşım ve kompleks yapılaşma gibi bir planlama yaklaşımı uygulanmıştır. Bu durumun doğal ve sosyo-kültürel kaynaklar üzerinde baskılar oluşturması ile kentsel sorunların çözümüne yönelik yeni planlama yaklaşımları geliştirilmiştir. Albrechts (2001), çalışmasında; kentlerde endüstrileşme ve beraberindeki teknolojik gelişmeler ile ortaya çıkan 
değişim sürecinin yaşam alanlarının etkili şekilde planlanmasını gerektirdiğinden bahsetmiştir. Kalkınma Bakanlığı'nın 2018 yılında hazırladığı, "Mekânsal Planlama Sistemine illişkin Değerlendirme Raporu'nda da; hızlı şehirleşme, bilgi ve iletişim teknolojilerindeki gelişmeler sonucu ortaya çıkan kentsel sorunların çözümünde planlamada kapsayıcı/geleneksel yaklaşımın yetersiz kaldığından bahsedilmiştir. Dolayısıyla yeni planlama anlayışları çerçevesinde; kentsel yerleşmelerin mekânsal yaşam kalitesinin artırılması temel hedef olmuştur. Öyle ki Ülkemizde Onuncu Kalkınma Planı " "Yaşanabilir Mekânlar ve Sürdürülebilir Çevre" hedefi ile yaşanabilirlik-mekân ilişkisini odağa alan bir yaklaşım öngörmüştür (Kalkınma Bakanlığı, 2018). Yeni planlama yaklaşımlarının temelinde; kentlerin doğal ve sosyo/kültürel tüm değerlerinin bütüncül bir şekilde ele alınması ile özgün ve nitelikli özelliklerinin vurgulanması yer almaktadır. Bu kapsamda kıyılar da kentsel peyzaj açısından önemli öğelerdir. Öyle ki tarih boyunca insanlar için su kenarları hep cazip olmuş ve yerleşimlerin birçoğu kıyı alanlarında kurulmuştur. Bu noktada kıyı alanları; balıkçıı olanakları, iklimsel özellikler, ticaret, savunma ve tarımsal intiyaçlar gibi etkenlerden dolayı, yaşama alanı olarak tercih edilmiştir (Bender, 1993; Hamamcıoğlu, 2005). Denize en uzak noktanın Orta Avrupa'da yalnızca $350 \mathrm{~km}$, Doğu Avrupa'da ise $700 \mathrm{~km}$ olması da (Duru,2003) kıyı alanları-ticaret ve ulaşım ilişkisinin bir sonucudur. Ekonomik anlamda da kıyı alanları önemlidir. İllerin ve Bölgelerin Sosyo-Ekonomik Gelişmişlik Sıralaması Araştırması'na göre (2017), sosyo-ekonomik gelişmişlik düzeyi en yüksek olan ilk 10 ilden 7'si kıyı illeridir (Sanayi ve Teknoloji Bakanlığı, 2019). Venedik, Bangkok, Amsterdam,Bari,Antalya, İzmir, İstanbul gibi birçok kent, su varlığı ve kıyısı sayesinde önemli gelişim göstermiş örnekler arasındadır. Kıyı alanlarının ulaşım, ticaret, rekreasyon-turizm ve ekolojik açıdan sağladığı olanaklar ile birlikte yoğun kullanılması bu alanların yönetimi ve planlanmasını gerektirmiştir (Garipağaoğlu ve ark., 2014).

Yüzölçümü olarak Türkiye'nin en küçük ili olan Yalova, coğrafi konumu, doğal özellikleri, kültürel değerleri, sosyo-kültürel değerleri ile ön plana çıkmış önemli bir kıyı kentidir. Ancak, kıyı ile kent arasındaki bağlantının zayıf olması, yapısal kullanımların bütüncül olarak kurgulanmaması ve buna bağlı mekânlar arasında kesintili erişilebilirlikler mevcuttur. Bu durum, Yalova kenti kıyı alanı için ile sürdürülebilir ve kentle bütünleştirilebilir bir mekânsal kurgunun planlanması gerekliliğini ortaya koymaktadır. Öyle ki AlexandriaWaterfront Small Area Plan (2012) ve Şolt (2018)'in de belirttikleri gibi; kıyı alanlarındaki kamusal mekân kazanımlarında ve bu mekânlara erişimde bir sürekliliğin arz etmesi gerektiği önemle vurgulanmıştır. Buradan yola çıkılarak çalışmada; Yalova merkez ilçesi kıyı bandı örneğinde kentsel peyzaj planlama odaklı mekânsal gelişim stratejilerinin belirlenmesi amaçlanmıştır.

\section{MATERYAL ve YÖNTEM}

\section{Materyal}

Çalışma alanı ana materyalini Yalova kenti kıyı alanı oluşturmaktadır. Yalova,Anadolu'nun kuzeybatısında Marmara Bölgesi'nin, Güney Marmara Bölümü'nün doğusunda, Samanlı Dağları'nın kuzeyinde bulunmaktadır. Yalova illi $28^{\circ} 45^{\prime}$ ve $29^{\circ} 35^{\prime}$ Doğu boylamları, $40^{\circ} 28^{\prime}$ ve $40^{\circ} 45^{\prime}$ Kuzey enlemleri arasında olup, kuzeyinde İstanbul, doğusunda Kocaeli ve güneyinde Bursa olmak üzere üç büyükşehrin ortasında yer almaktadır (Şekil 1) (Özdemir ve Bahadır, 2007).
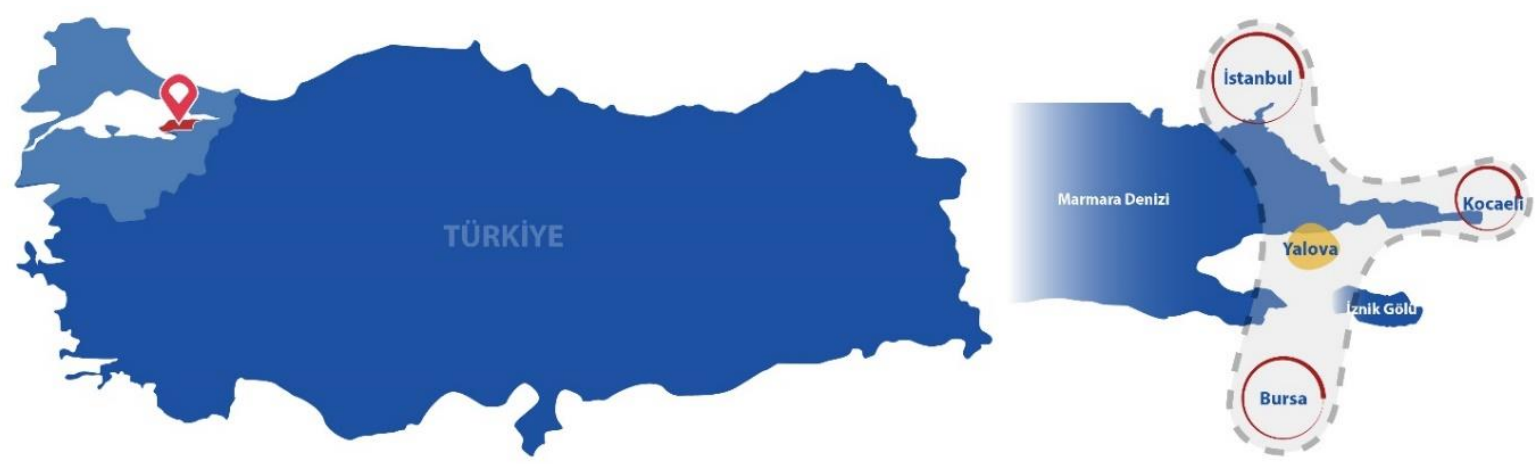

Şekil 1. Kentin ülke içinde bulunduğu konum ve çevre iller arasındaki lokasyonu

Figure 1. The location of the city in the countryandits location between neigh boring provinces

Yalova; yüzölçümü açısından Türkiye'nin en küçük ili olup, 1995 yılında il statüsüne geçmiştir. il 1. Derece deprem kuşağı içinde yer almaktadır. $110 \mathrm{~km}$ uzunluğunda bir kıyı şeridine sahiptir (Kentsel Vizyon Platformu, 2011). Yalova'nın iklimi, Akdeniz ve Karadeniz iklimleri arasında bir geçiş niteliği taşımakla 
birlikte, iç kesimlerde karasal iklim özellikleri görülmektedir. Genellikle ilde, yazlar kurak ve sıcak, kışlar ılık ve bol yağışıdır (T.C. Yalova Valiliği, 2020).

Çalışma alanı olan Merkez ilıçe kıyı bandı, $8 \mathrm{~km}$ uzunluğunda olup 530ha'ık bir genişliğe sahiptir (Şekil 2). Kentsel peyzaj açısından önemli olan kıyı, kente değer kazandırma konusunda önemli bir öğedir. Bu yüzden kentsel odakları birleştirebilme, fırsatlar yaratabilme potansiyelinin olduğu saptanan Yalova, Merkez İlçe kıyı bandının, kesintisiz, bütüncül bir mekânsal süreklilik konusunda eksiklikleri olması ve kent-kıyı entegrasyonunzayıflığı gibi sebeplerle çalışma alanı olarak belirlenmiştir.

Kıyı bandındaki aktif kullanım mevcut durumda sadece dolgu alanlarında sınırlı kalmaktadır. Bunun dışındaki mekânsal kullanımlar sosyal altyapı ve günübirlik turizm alanları olarak tesis edilmektedir. Bazı park alanlarının ise mekânsal olarak bir tanıma sahip olmadığı, pasif ve atıl durumda oldukları gözükmektedir.

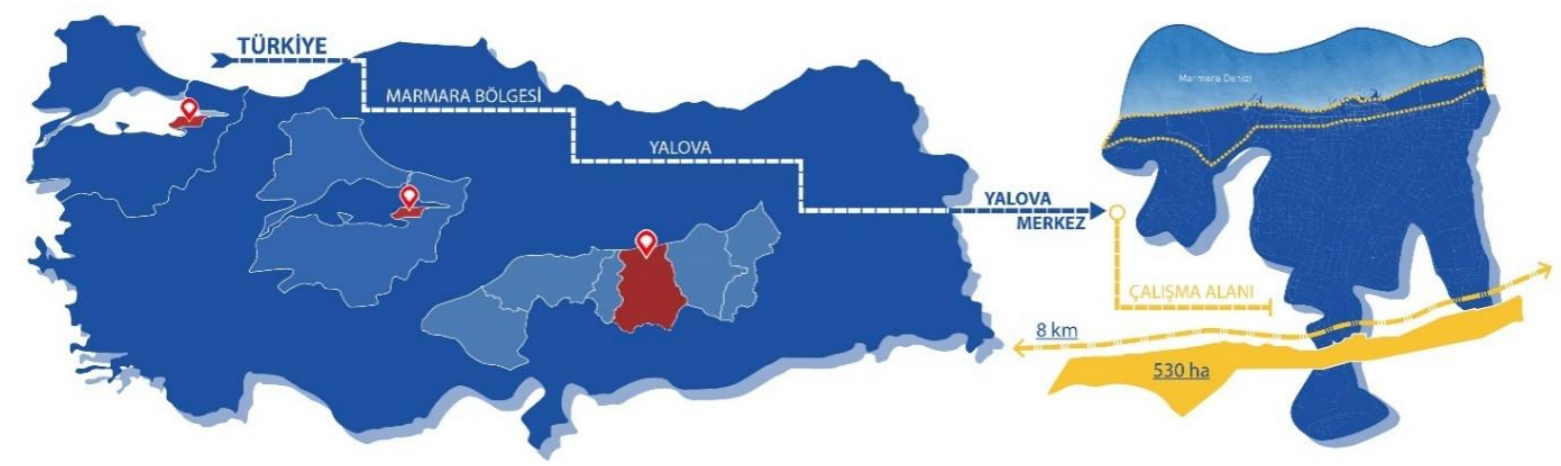

Şekil 2.Çalışma alanı konumu

Figure 2.The study location

Konu ve alanla ilgili yapılmış makale, tez, rapor vb. çalışmalar ile Yalova'ya ait ilgili kurum ve kuruluşlardan elde edilen raporlar ve Yalova illi $1 / 50.000$ ve $1 / 25.000$ ölçekli Çevre Düzeni Planları ile $1 / 5.000$ ve $1 / 1.000$ ölçekli nazım ve uygulama imar planları ile raporları çalışmada kullanılan ikincil materyaller olmuştur.

\section{Yöntem}

Çalışma kapsamında kullanılan yöntem; çalışma alanına ilişkin amaç ve kapsamın belirlenmesi, Yalova'ya ilişkin peyzaj değerlerinin belirlenmesi, kent merkezi ile kıyı bandı arasındaki kurgunun saptanması, Swot Analizi ve mekânsal gelişim stratejilerinin belirlenmesi olmak üzere beş ana başlık çerçevesinde geliştirilmiştir.

1. Aşama: çalışma alanına ilişkin amaç ve kapsamın belirlenmesi: Çalışmada, "kıyı alanları ekolojik özellikleri ve mekânsal değerleri açısından kentler için önemli bir eleman olup, planlama çalışmalarında kentin ana gelişimi ile uyumlu ve dengeli bir yaklaşım kapsamında değerlendirilmelidirler" savından hareketle; Yalova merkez ilçesi kıyı bandı örneğinde kentsel peyzaj planlama odaklı mekânsal gelişim stratejilerinin belirlenmesi amaçlanmıştır. Bu kapsamda çalışmada "Yalova iline ait genel özellikler nelerdir?", "Kent merkezi ile kıyı bandı arasındaki ilişki nasıldır?", "Mevcut duruma ilişkin güçlü ve Zayıf yönler ile fırsatlar ve tehditler nelerdir?" ile "Kıyı odaklı mekânsal gelişim stratejileri neler olmalıdır?" sorularına yanıt aranmıştır.
2. Aşama: Yalova'ya ilişkin peyzaj değerlerinin belirlenmesi: $\mathrm{Bu}$ aşamada; "Yalova iline ait genel özellikler nelerdir?" sorusuna yanıt aranmıştır. Bu kapsamda; il düzeyinde doğal ve sosyo-kültürel yapıya ilişkin genel değerlendirmeler yapılmıştır. Değerlendirmeler kapsamında kıyı alanını etkileyebilecek ulaşım, nüfus, ekonomik yapı, topoğrafya ve bitki örtüsüne ilişkin genel bilgiler ele alınmıştır.

3. Aşama: Kent merkezi ile kıyı bandı arasındaki kurgunun saptanması: Bu aşamada da; "Kent merkezi ile kıyı bandı arasındaki ilişki nasıldır?" sorusuna yanıt aranmıştır. Bu kapsamda öncelikle; tarihi süreç içerisinde (1984, 1994, 2004 ve 2019 yılları arasında) kent makroformunun almış olduğu değişim kent merkezi çerçevesinde irdelenmiştir. Sonrasında; kıyı ile kenti birbirine bağlayan ulaşım aksları, kıyı ile kenti etkileyen odaklar, kıyı ile kent merkezi arasındaki yürünebilirlik odaklı erişim ve arazi kullanım biçimleri ortaya konmuştur. Her bir ana başlık şekilsel ifadeler çerçevesinde değerlendirilmiştir.

4. Aşama: Swot Analizi: Bu aşamada; ilk üç aşamadan elde edilen veriler ve arazi gözlemlerinden yararlanılarak, Swot Analizi çerçevesinde mevcut duruma ilişkin güçlü ve zayıf yönler ile firsatlar ve tehditler saptanmıştır.

5. Aşama: Mekânsal gelişim stratejilerinin belirlenmesi: Bu aşamada; "Kıyı odaklı mekânsal gelişim 
stratejileri neler olmalıdır?" sorusuna yanıt aranmıştır. Bu kapsamda; beş ana hedef çerçevesinde mekânsal gelişim stratejileri geliştirilmiştir. Stratejilerin geliştirilmesinde; kentsel yaşam kalitesi çerçevesinde, kent ile kıyıyı bütünleştiren, doğal ve kültürel değerleri gözeten, sürdürülebilir ve insan odaklı bir yaklaşım benimsenmiştir.

\section{BULGULAR ve TARTIŞMA}

\section{Yalova'ya ilişkin Peyzaj Değerlerinin Belirlenmesi}

Ulaşım yapısı:Stratejik olarak önemli bir noktada konumlanan Yalova, Kocaeli, Bursa ve ìstanbul gibi illerin oluşturduğu üçgenin merkezinde, ulaşım ve bağlantı noktasında yer almaktadır. Yalova'ya denizyolu ile ulaşım İstanbul'da üç noktadan gerçekleştirilmektedir. Biri Avrupa yakasında Yenikapı'dan ikisi Anadolu yakasında Pendik ve Eskihisar'dan yapılmaktadır. Bununla birlikte i̇stanbul, Bandırma, Derince Liman bağlantıları ile bölgesel lojistik merkezi olma imkânına sahiptir (MARKA, 2018).Yalova, karayolu bağlantıları ile İstanbul, Bursa ve Kocaeli illerine bağlıdır. Yalova'dan; Bursa'ya (69 km), Kocaeli'ne $(63 \mathrm{~km})$, İstanbul'a $(174 \mathrm{~km})$ günübirlik ulaşım mümkündür. Yalova-Bursa bağlantısı ile Yalova'dan, İç Anadolu Bölgesi ile Ege ve Akdeniz Bölgesi'ne de ulaşmak mümkündür (Yalova il Kültür Turizm Müdürlüğü, 2020).

Havayolu ulaşımı açısından Yalova'da havaalanı bulunmamakla birlikte; Bursa-Yenişehir Hava Limanı, Kocaeli-Cengiz Topel Hava Limanı ile İstanbul-Sabiha Gökçen Hava Limanı'ndan yararlanılma potansiyeli bulunmaktadır.

Nüfus ve illçelere ilişkin genel özellikler:Yalova illi nüfusu 2019yılı itibariyle 270.976kişidir. 2019 yılında Yalova'nın yıllık nüfus artış hızı \% 32,8 olup, nüfus yoğunluğu açısından da, $\mathrm{km}^{2 \prime}$ ye düşen 320 kişinin yer aldığı bir nüfus yoğunluğuna sahiptir (TÜiK, 2019). Yalova'da 6 ilçe mevcuttur. İlçelerin özelliklerine bakıldığında hizmet, eğitim, sağlık ve organize tarım sektörleriyle en kalabalık ilçe, Merkez illçe olmuştur. Çiftlikköy ve Altınova ağırlıklı sanayi sektörü ile gelişmiştir. Çınarcık yaz turizmi, Termal ve Armutlu da sağlık turizmi açısından ön plandadır.

Yalova ilinin ekonomisinde ilk iki sırayı \%42,4' le sanayi ve $\% 41,8^{\prime}$ le hizmet sektörü alırken tarım \%4,24 lük bir paya sahip olmuştur.Kentin başlıca ekonomik değerleri; tarımsal üretim, turizm, kimyasal ürünler sanayisi ve gemi inşa sanayisidir. Öyle ki; Marmara Kalkınma Ajansının hazırlamış olduğu, Yalova il Yatırım Destek ve Tanıtım Stratejisi 2018 Yılı Eylem Planı'na göre; gemi inşa sanayisinde 22 tersane ile İstanbul'dan sonra
Türkiye 2.si konumundadır. Diğer yandan Yalova, süs bitkisi üretimi konusunda Antalya ve İzmir'den sonra 3.Sırada yer almaktadır. Turizm alanında kıyı turizmi ile birlikte termal suları ve sağlık turizmi alanında gelişim göstermektedir (MARKA, 2018).

Topoğrafik yapı ve bitki örtüsü:Kent doğu tarafındaki düzlük alanlar dışında batıdan doğuya doğru Samanlı Dağları ile çevrilidir. En yüksek noktası 926 m'dir. Maki ve ormanların oluşturduğu bitki örtüsü, Karadeniz Kıyı Silsilesi ile Akdeniz Florasının iç içe geçtiği bir ortamı temsil etmektedir. \%58'lik dilimi orman alanı olan kentin bu alanlarında Kayın (Fagus sp.), Meşe (Quercus $s p$.$) , Gürgen (Carpinus sp.), Kızılcık (Cornus sp.) ve$ Ihlamur (Tilia sp.) türleri sık görülmektedir (TC Yalova Valiliği, 2020).

Depremsellik durumu: Yalova 1. derece deprem bölgesinde, aktif fay hatlarının geçtiği bölgede yer almaktadır.

\section{Kent Merkezi ile Kıyı Bandı Arasındaki Kurgunun Saptanmasına ilişkin Bulgular}

Tarihi süreç içerisinde kent makroformunun gelişimi:Google Earth Programı'nın zaman kaydırıcı özelliği kullanılarak 1984, 1994, 2004 ve 2019 yıllarına göre kent makroformundaki değişim (Şekil. 3)'de verilmiştir. 1984'te İstanbul'a bağlı bir ilçe olan Yalova'nın yerleşimi sahilde toplanmıştır. 1994 yılına gelindiğinde 1985 ve 1900 yılları arasında Balkanlardan gerçekleşen göçlerle doğu ve batı yönlü genişlemiştir. 2004'e gelindiğinde artık 9 yıllık il olan Yalova 17 Ağustos depreminden sonraki yeniden yapılaşma ve Güneydoğu, Doğu Anadolu Bölgelerinden aldığı göçlerle genişlemeye devam etmiştir. 2019 yılına kadarki bu süreç içerisinde gelişen sanayileşmenin etkisiyle göç almaya devam edip güney yönündeki düz arazilere doğru genişlemiştir (Şekil 3).

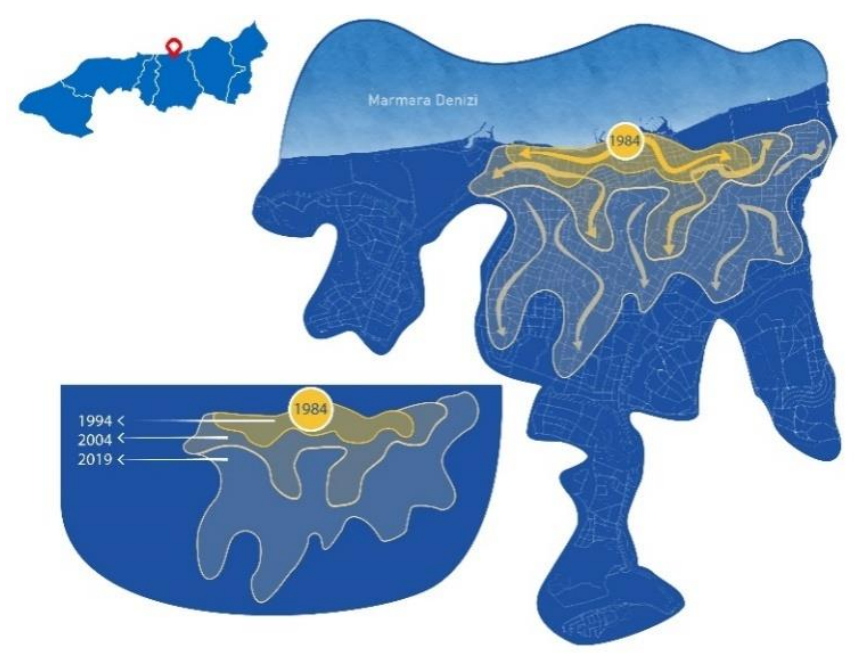

Şekil 3. Tarihi süreç içerisinde kent makroformu 
Figure 3. Urban macroform in the historical process

Ana ulaşım aksları:Kentin doğusunu merkeze yaklaştıran Yalova-İzmit yolu daha sonra Yalova-Bursa istikametine devam ederek güney yönlü ilerlemektedir. Armutlu Yarımadası'nı çevreleyerek batı yönüne doğru ulaşım bağlantısını, kent merkezinde kıyıya paralel ilerleyen Şehir Ömer Faydalı Caddesi sağlamaktadır (Şekil 4).

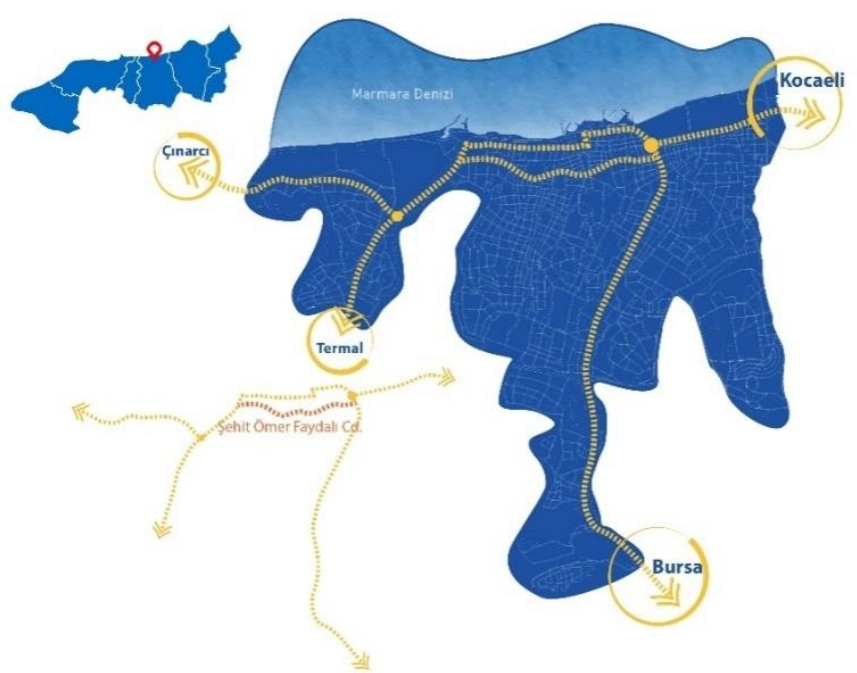

Şekil 4. Kentin ana ulaşım aksları

Figure 4. Main transport axes of the city

Kentsel odaklar:Kıyı ile kent arasındaki etkileşimi güçlendirecek ana odaklar belirlenmiştir. Bu odaklar; kentin yoğun olarak kullanılan, simge ve anıt niteliği taşıyan, ekonomik, kültürel ve tarihi değeri yüksek olan mekânlarından seçilmiştir (Şekil 5).

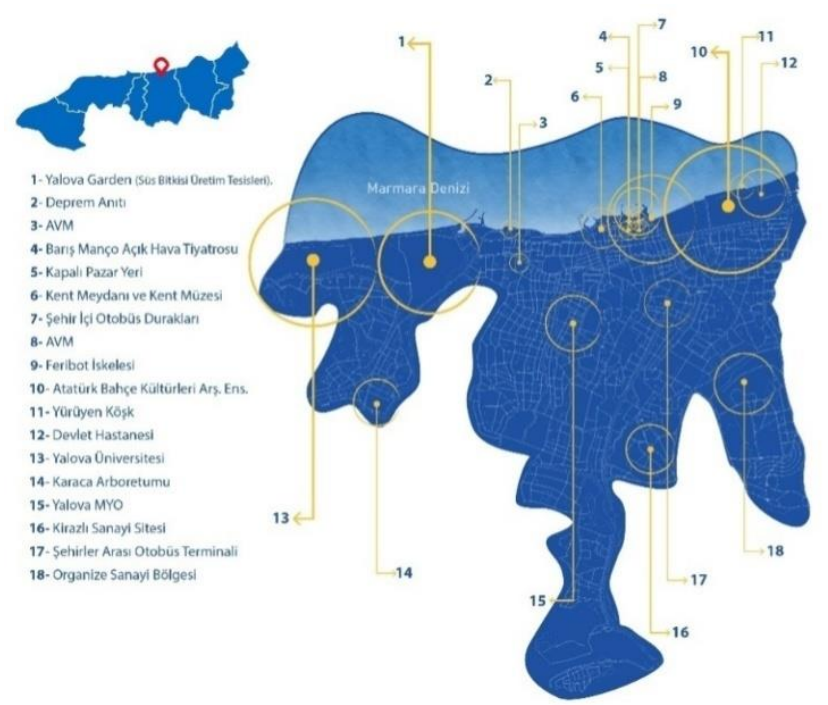

Şekil 5. Kentsel odaklar Figure 5.Urban focuses
Erişilebilirlik durumu:Yalova kıyı bandının kent merkezi ile erişilebilirlik durumunu belirlemek için, yürünülebilirlik ölçütleri çerçevesinde kent meydanı merkez alınarak 500'er metrelik arayla 2000metreye kadar olan mesafelerdeki etki alanı belirlenmiştir (Şekil 6). Etki çapının oldukça geniş alan kapladığı bu durumdan kent merkezinin kompakt bir yapıda olduğu çıkarımı yapılabilir.

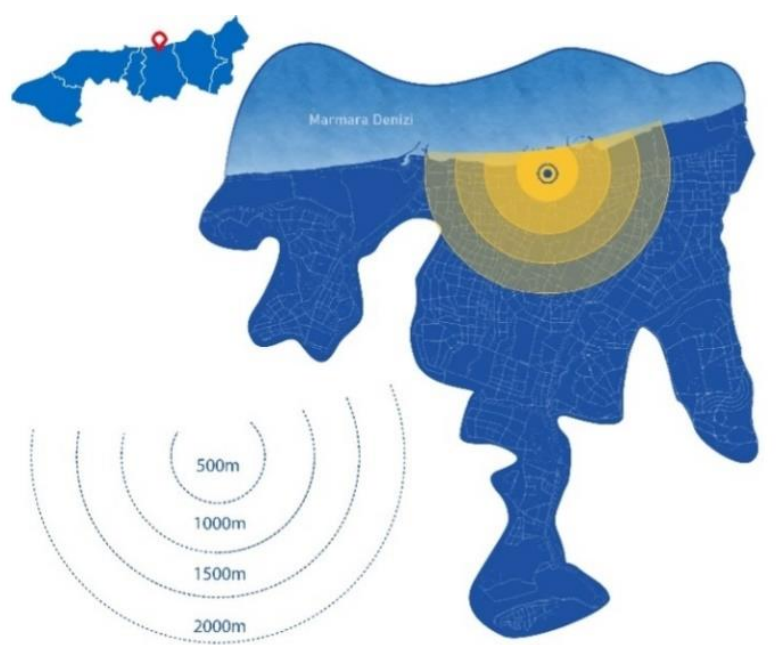

Şekil 6. Kent merkezinin $2000 m^{\prime}$ lik etki alanı Figure 6. 2000m impact area of the city center

Kentsel donatılar:Kent merkezinde yeşil alan dağılımında aktif yeşil alanlar (park alanları ve spor alanları) pasif yeşil alanlar (refüjler, mezarlık alanları, ağaçlandırılacak alanlar ve orman alanları) ve tarım alanları verilmiştir. Buna göre, aktif yeşil alanların büyük bir bölümünün kent merkezinin güneydoğu bölümünde, tarım alanlarının ise yine güneydoğu ile birlikte güneybatı bölümünde yer aldığı saptanmıştır (Şekil 7).

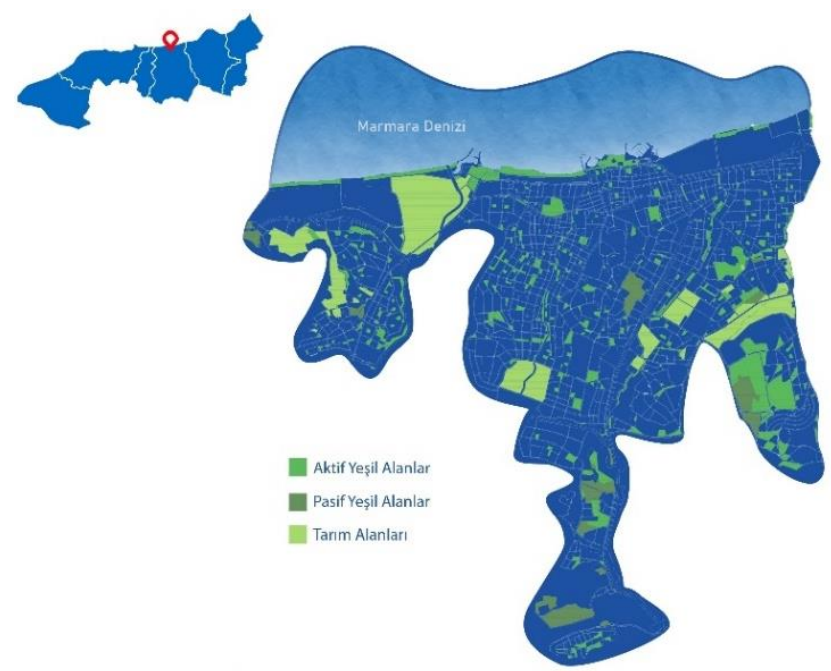

Şekil 7. Kentsel yeşil alanlar (Anonim, 2019) Figure 7.Urban green spaces 
Mevcut ve öngörülen konut alanlarına ilişkin harita Şekil 8'de verilmiştir. Şekil 8'e göre; gelişme konut alanlarının konumu dikkate alındığında, kentin güney yönlü gelişim göstereceği çıkarımı yapılabilir.Ticaret alanları ve diğer donatı alanlarına ilişkin haritalar Şekil 9 ve Şekil 10'da verilmiştir.

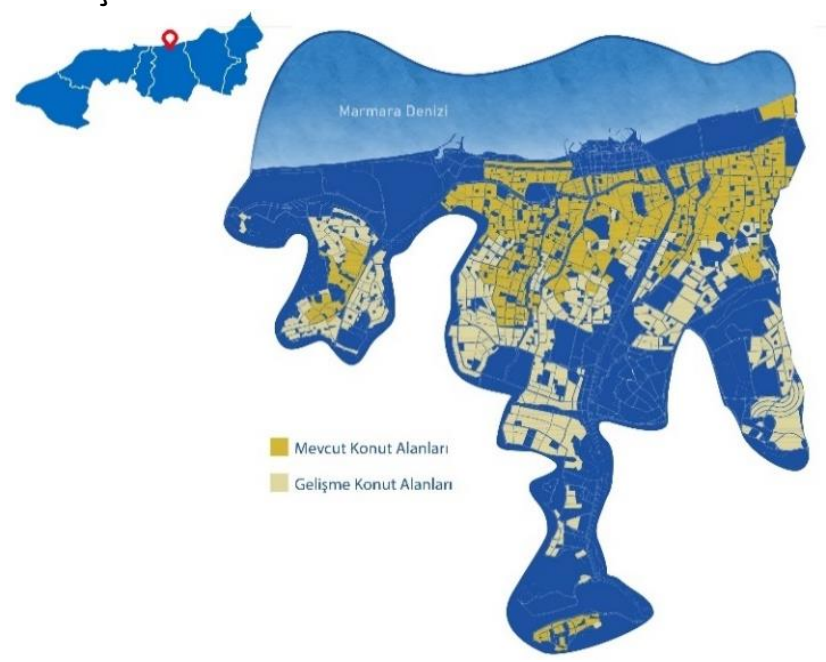

Şekil 8. Mevcut ve gelişme konut alanları

Figure 8. Existing and development residential areas

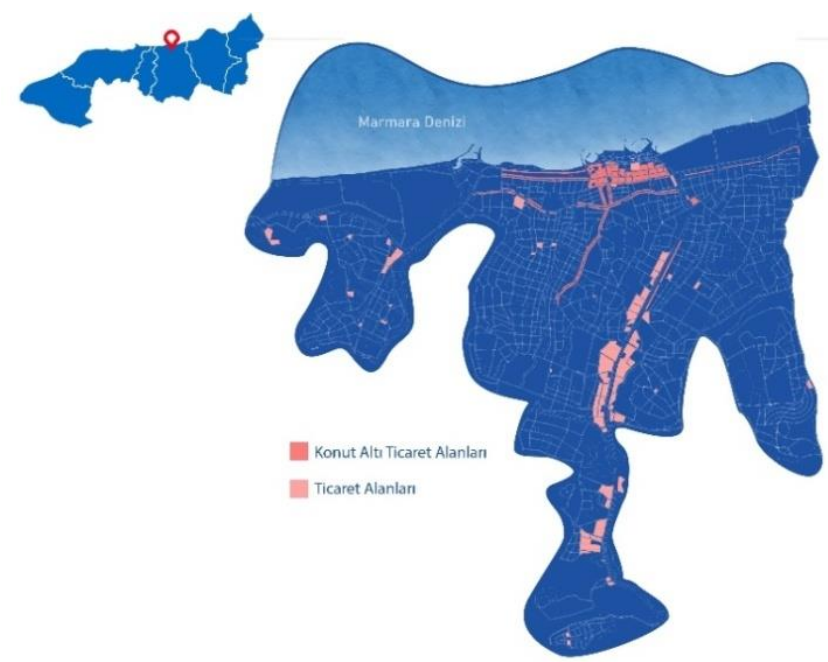

Şekil 9. Ticaret alanları (Anonim, 2019)

Figure 9. Trade areas

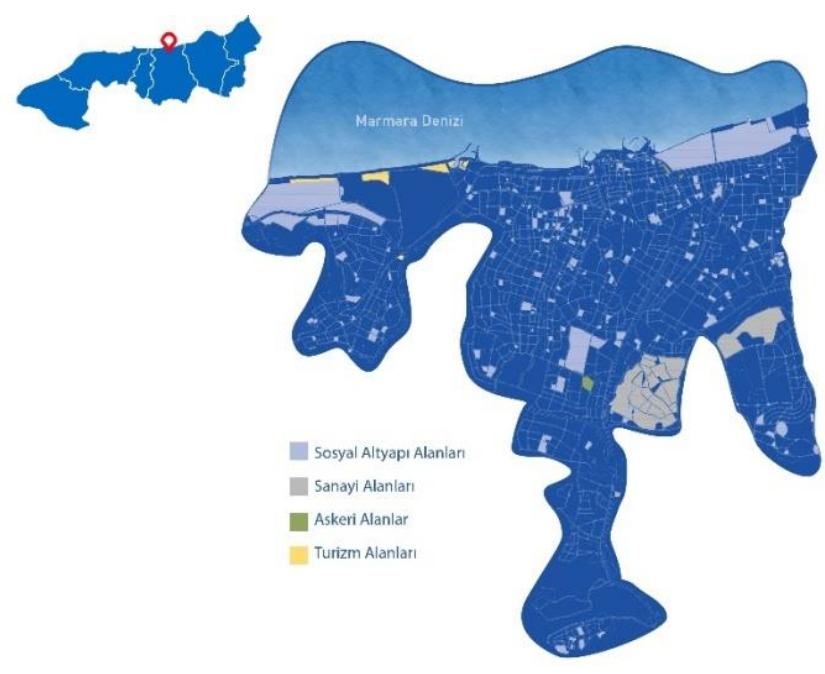

Şekil 10. Diğer kentsel donatılar (Anonim, 2019).

Figure 10. Other urban services

Kıyı ile kent merkezi arasında kalan doğal eşik olarak kabul edilebilen 4 adet dere mevcuttur (Şekil 11).

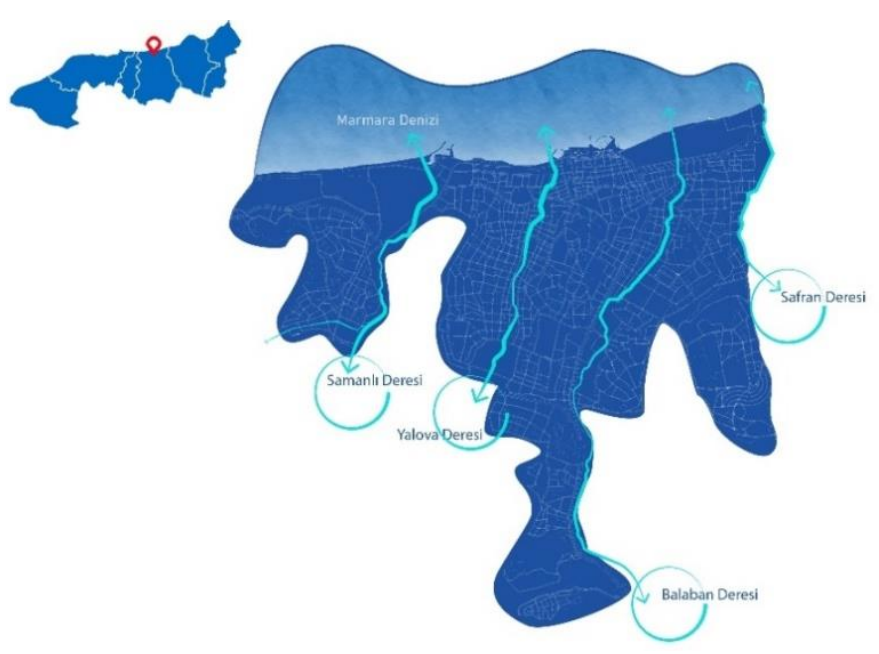

Şekil 11. Merkez ilçe hidrografik haritası

Figure 11. Central district hydrographic map

\section{SWOT Analizine ilişkin Bulgular}

Yöntem çerçevesinde elde edilen bulgularla alana ilişkin güçlü ve zayıf yönler belirlenmiştir (Çizelge 1). Alana ilişkin derelerin varlığı, erişilebilirlik imkânları, ana odak alanları ile etkileşim potansiyeli güçlü yönler olarak tanımlanırken; konut alanlarının yoğun bir biçimde kıyı alanında yoğunlaşması, yeşil alan-kıyı ilişkisinde kopukluklar olması da zayıflıklar olarak tespit edilmiştir.

\section{Hedeflerin Belirlenmesi}

Çalışma kapsamında; kıyı alanının kent ile ilişkisinin kurgulanarak, görsel ve fiziksel kalitenin arttırılması yoluyla sosyal, kültürel ve çevresel anlamda bir odak 
oluşturulması amaçlanmıştır. Bu kapsamda 5 ana hedef öngörülmüştür. Hedefler ve alt hedefler Çizelge 2 . de

Çizelge 1. SWOT analizi

Table 1. SWOT analysis aşağıda sunulmuştur.

\section{Güçlü Yönler}

Zayıf Yönler

- Kıyı şeridine bağlanan ana derelerin varlığı

- İstanbul'a yakınlık ve kısa süreli denizyolu ulaşım imkânları

- Tarım alanları ile güçlü ilişki

- Kıyı ile kent arasındaki etkileşimi güçlendirecek ana odaklar

- Kıyı ile ilişkili güçlü ulaşım bağlantıları

Firsatlar

- $\quad$ Tarımsal niteliği ile güçlü üretim değeri

- $\quad$ İstanbul, Bursa ve Kocaeli büyük şehirlerinin oluşturduğu üçgenin merkezinde konumlanması

- Uluslararası hava limanlarına yakınlığı ile yurt dışından erişilebilirliğinin olması

- Bütünleşik kıyı yönetimi kapsamında değerlendirilme potansiyeli
- Konut alanlarının yoğunluğu

- Ticaret alanlarının belirli bölgelerde yoğunlaşmas

- Yeşil alan dağılımlarının parçacıl yapıda olması ve kıyı ile entegre edilememesi

- Yaya odaklı ulaşımla ilgili yetersizlikler

Çizelge 2. Yalova ilii merkez ilçe kıyı bandına ilişkin hedefler

Table 2. Targets for the central district coast line of Yalova Province

\section{Tehditler}

1. Derece deprem kuşağında yer alması ve bölgenin, yüksek derecede jeolojik yer hareketliliği potansiyeli taşıması

- $\quad$ Giderek artan deniz kirliliği

- Göç alması

- C Çevresindeki büyük kentlerin dışladığı sanayinin sosyal ve çevresel baskısı altında olması.

\section{Hedefler}

\begin{tabular}{l} 
Hedefler \\
\hline Hedef 1: Aktif yeşil büyümenin sağlanması \\
(Şekil12)
\end{tabular}

(Şekil12)

Hedef 2: Doğal değerlerin koruma kullanım dengesinin sağlanması (Şekil 13)

Hedef 3:Mekânsal kararlarla sosyo-ekonomik kararların bütünleştirilmesi (Şekil 14) aktif bir sahil bandı yaratmak (Şekil 15)

Hedef 5:Ulaşım araçlarının çeşitlendirilmesi

(Şekil 16)
1.1. Pasif mekânların aktifleştirilmesi, yeni alan kazanımlarının elde edilmesi.

1.2. Kentsel donatı ve odakların kıyı ile entegrasyonu.

1.3. $1 / 50.000$ ÇDP'na göre alt merkez Çiftlikköy ile birlikteliğin kuvvetlendirilmesi.

1.4. Kompakt kent kimliğinin ön plana çıkarılması.

2.1. Doğal kaynakların yapısal çevreyle entegrasyonu.

2.2. Doğal sistemin, ticaret aksı ile bütünleştirilip kentin kıyıdan uzak bölgelerine açılan koridor biçiminde iç kesimlerden sahile uzanan bir kurgu oluşturulması.

3.1. Kente sosyo-ekonomik katkı sağlaması.

3.2. Organize tarım alanlarının (Süs Bitkileri Üretim Tesisleri ve Atatürk Bahçe Kültürleri Merkez Araştırma Enstitüsü) kıyı ile kente entegrasyonun sağlanarak bir mekânsal kullanıma dönüştürülmesi ve aynı zamanda kentliye ve konuklarına tanınırlık, bilinç ve bilgi kazandırılması.

4.1. Ticaret ve sosyal donatı alanlarının kıyı ile bütünleşik kurgulanması.

4.2. Kültürel mirasların kıyıya entegrasyonu.

4.3. Kamusal kullanımların arttırılması. Yeni yeşil kazanımların elde edilmesi.

5.1. Yaya odaklı ulaşımın güçlenmesi.

5.2. Kent içi bisikletli ulaşımın, kesintisiz sağlanması 


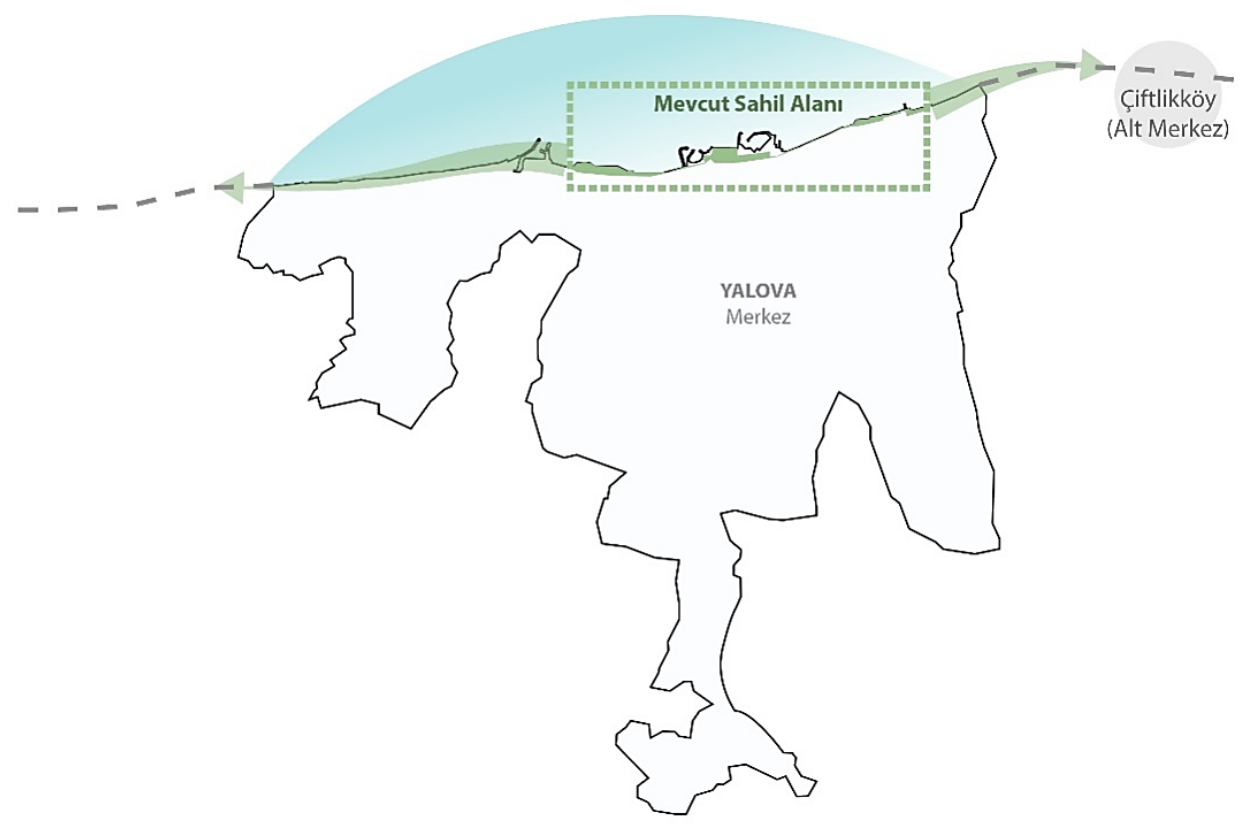

Şekil 12. Aktif yeşil büyüme

Figure 12. Active green growth

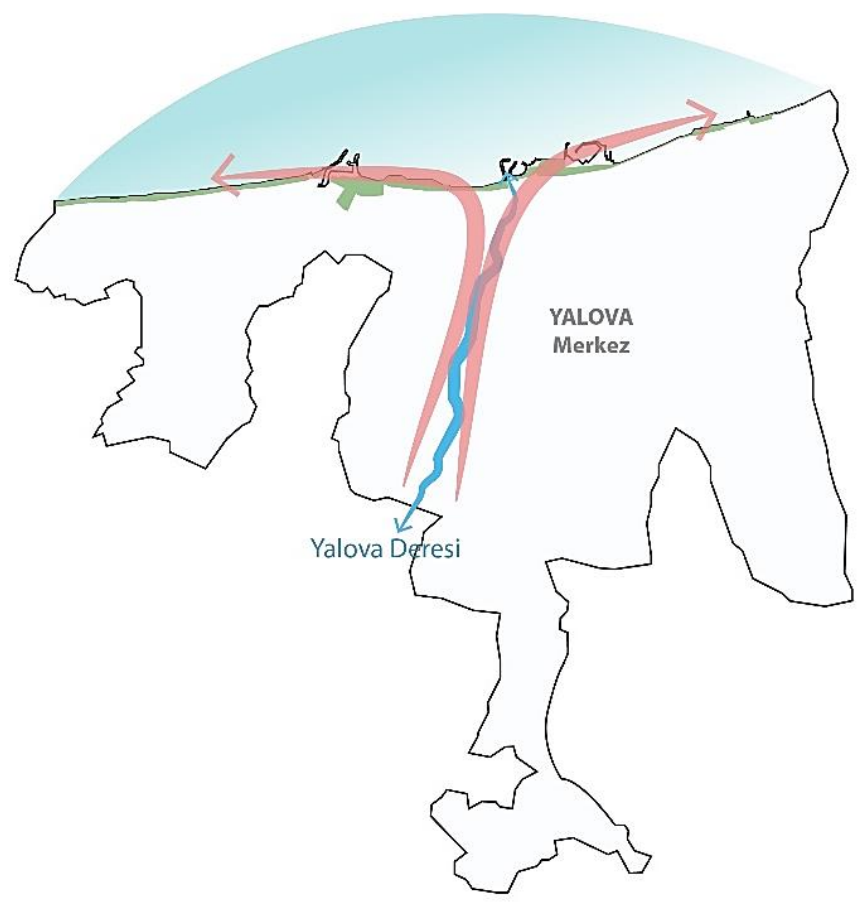

Şekil 13. Doğal değerlerin korunması

Figure 13. Conservation of natural values 


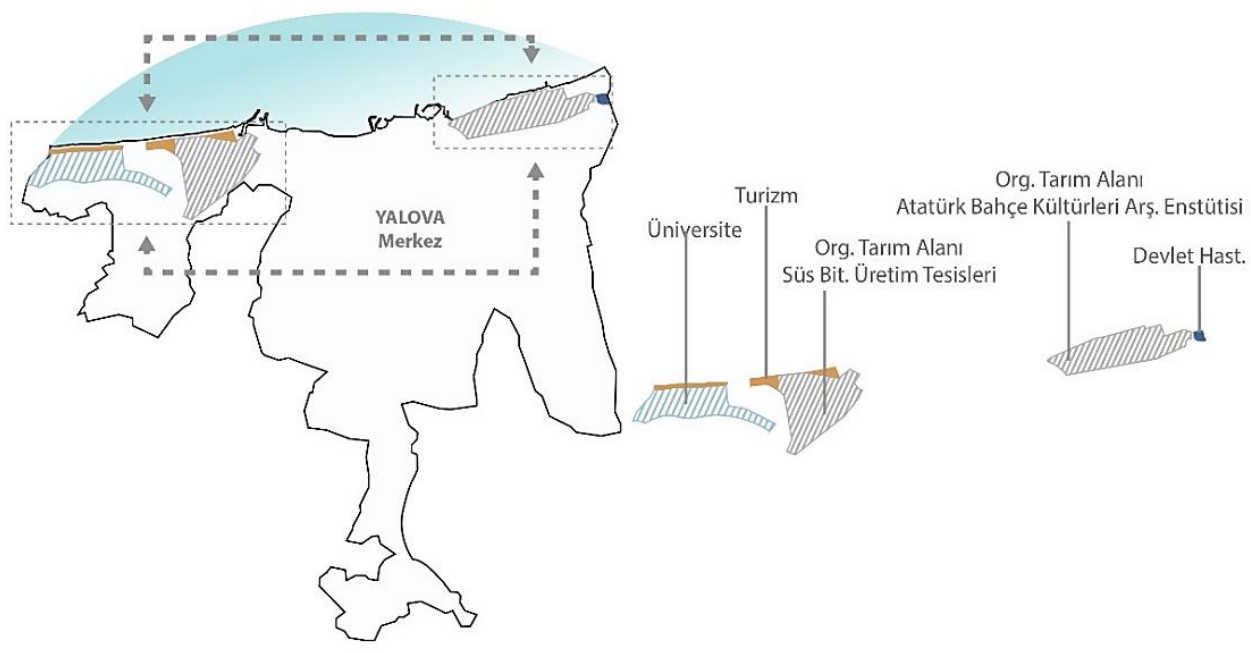

Şekil 14.Sosyo-ekonomik donatılar

Figure 14. Socio-economic services

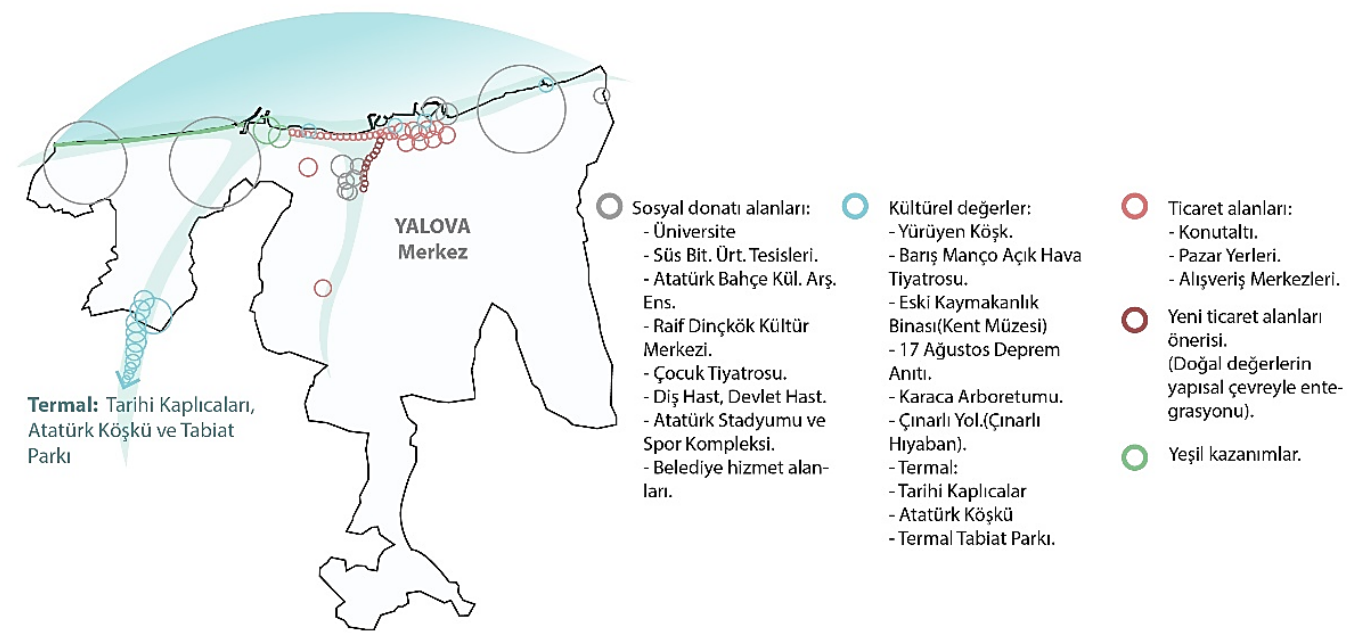

Şekil 15. Sosyal, kültürel, ticari ve yeşil odaklar

Figure 15. Social, cultural, commercial and green focuses

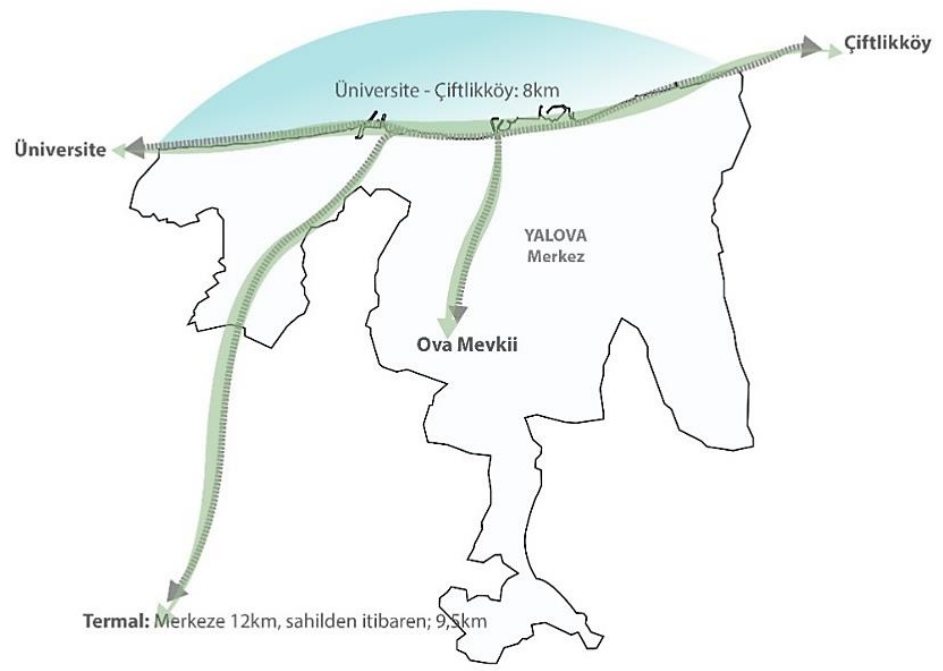

Şekil 16. Erişilebilirlik

Figure 16. Accessibility 


\section{SONUÇ}

Bu çalışmada "Kıyı alanları kent için önemli bir görsel, fiziksel ekolojik çekim alanıdır ve bu alanların dikkate alınması önemli bir konudur" savından hareketle; Yalova merkez ilçesi kıyı bandı örneğinde kentsel peyzaj planlama odaklı mekânsal gelişim stratejilerinin belirlenmesi amaçlanmıştır. Bu amaçla; Yalova'ya ilişkin peyzaj değerleri belirlenmiş, kent merkezi ile kıyı bandı arasındaki kurgunun saptanması için çeşitli değerlendirmeler yapılmış, Swot Analizi çerçevesinde güçlü ve zayıf yönler saptanmıştır. Bu çerçevede, kıyının kent için önemli olan odakları birleştirme, fırsatlar yaratabilme potansiyelinin olduğu, kesintisiz bir kıyı şeridi konusunda eksikliklerinin ve kent ile ilişkisinin kurulmaması gibi sorunlarının olduğu ortaya çıkmıştır. $\mathrm{Bu}$ çerçevede, sürdürülebilir hedefler belirlenmiş ve bazı üst ölçekli mekânsal gelişim stratejileri önerilmiştir. Yalova ili tarihsel süreç içerisinde önemli merkezlere en yakın yerleşme olması bakımından coğrafi öneme sahip olmanın yanı sıra, Cumhuriyet dönemi ile birlikte tarihsel ve kültürel değerleri ile de öne çıkmaktadır. Üst ölçekte ülkesel öneme sahip illerle çevrelenmiş olması ve bu illerin ulaşımında bağlantı noktasında bulunması ve tarımsal çeşitlilik de kent için önemlidir (Çevre ve Şehircilik Bakanlığı, 2018).

Mekânsal gelişim çerçevesinde; kıyı bandı mevcut kullanım durumuna ve potansiyellerine göre yatay ve dikey eksen şeklinde mekânlara bölünmüştür (Şekil 17). Yatay eksen, kıyı bandındaki mekânsal kurgunun tutunacağı omurga olurken, dikey eksende onun kentin içine uzanan kolları durumundadır. Yatay ve dikey eksen çerçevesinde, aktif bir sahil bandı oluşturulması planlanmıştır. "Aktif Sahil Bandı", kıyı bandı üzerindeki birçok pasif mekânın aktif hale dönüştürülmesiyle, "12 Aylık Kullanım Sistemi", kente özgü, yıl boyu aktif olan değerlerin kıyı bandına kazandırılmasıyla gerçekleşmektedir.Kıyı bandı ile kenti bağlayan yerlerde; üniversite odak alanı,organize tarım odağı, yeşil odak, sosyo-kültürel odak, kentsel odak başlıkları çerçevesinde odak alanlar belirlenmiştir (Şekil 18).

\section{MEKANSAL PLANLANLAMA DIYAGRAMI}

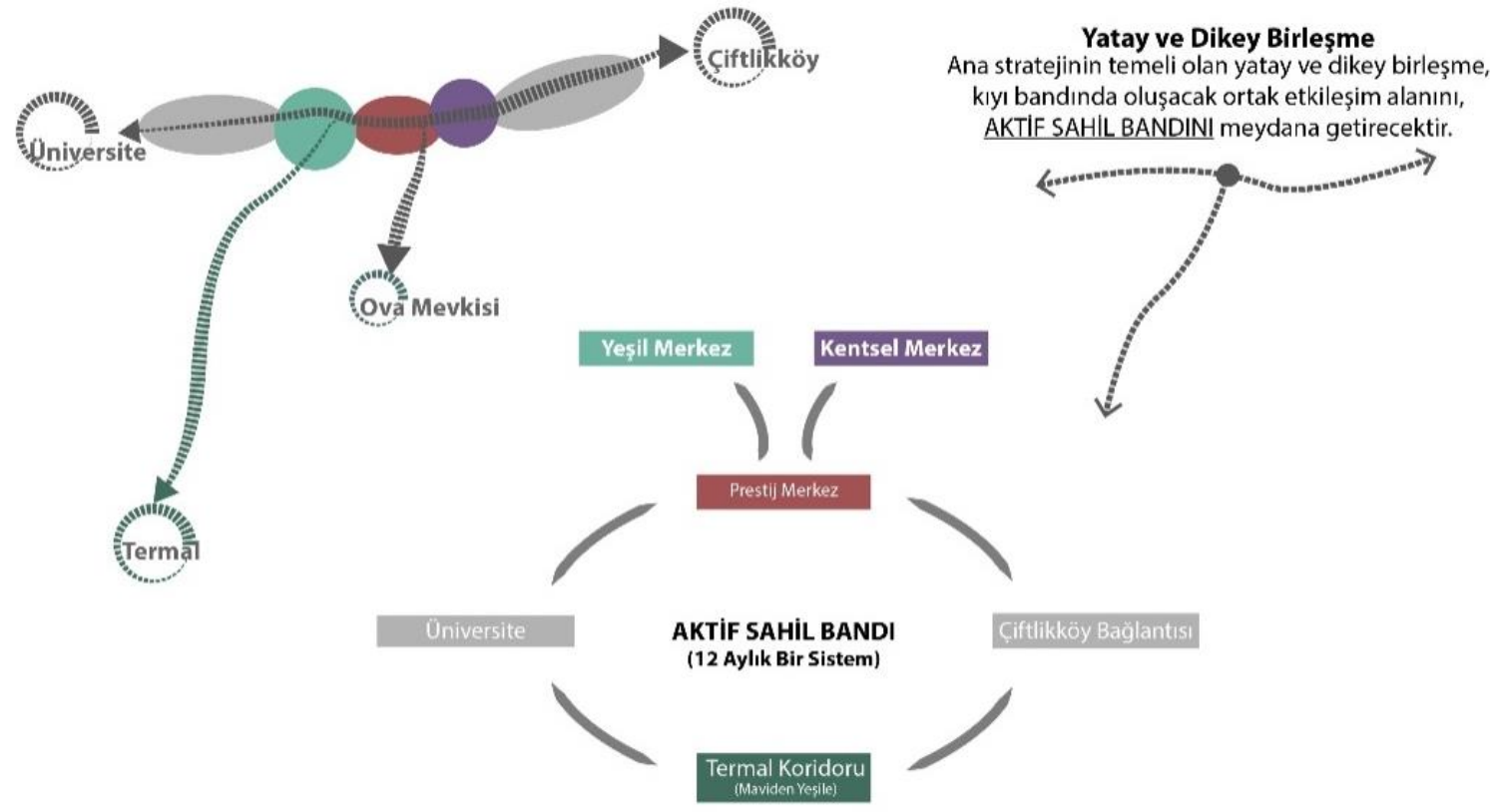

Şekil 17. Mekânsal planlama diyagramı

Figure 17. Spatial planning diagram 


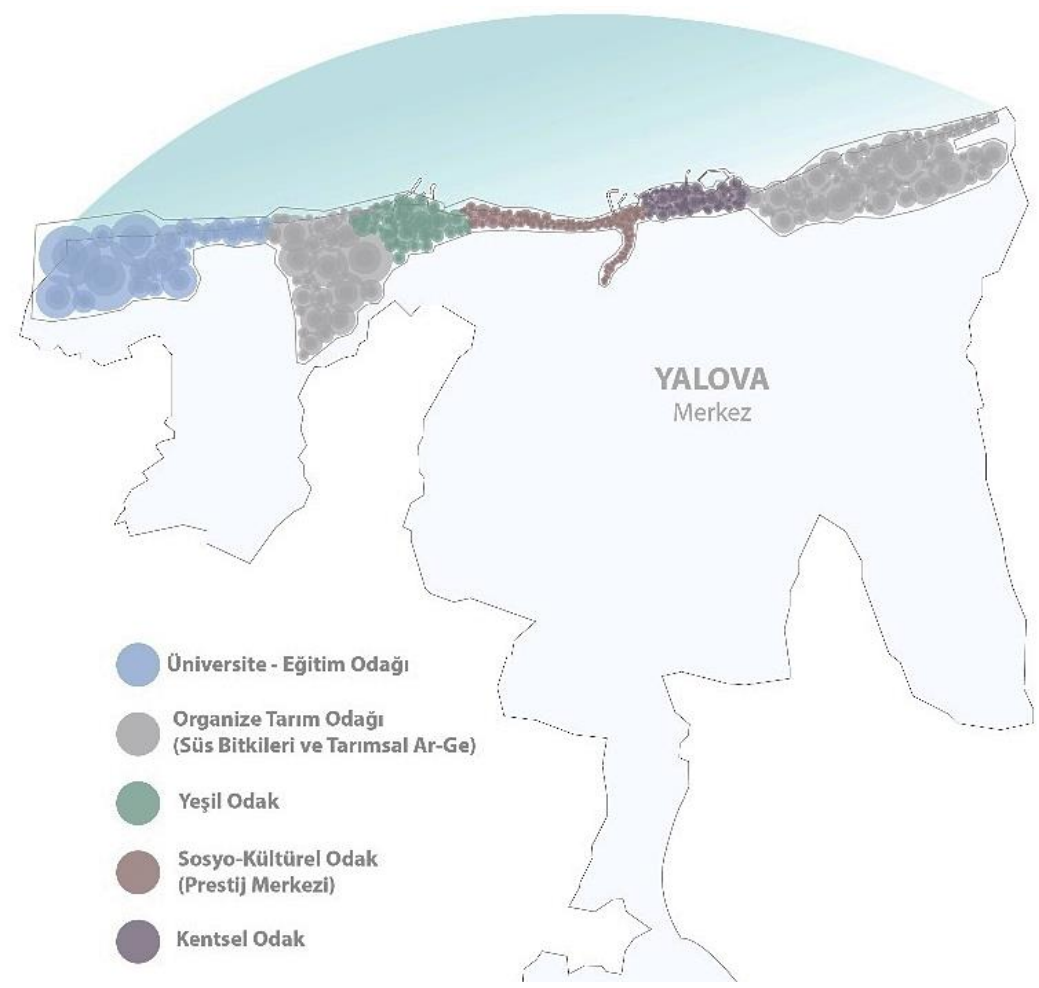

Şekil 18. Odak alanlar

Figure 18. Focus areas

Üniversite eğitim odağı: Üniversite yerleşkeleri, bulundukları bölgenin fiziksel, sosyal, kültürel ve ekonomik gelişimine etki eden kentsel donatılardır. Yalova Üniversitesi Yerleşkesi, yeni birimlerin inşasının sürmesiyle günümüzde büyüme sürecindedir. Fakat yerleşke planlaması, kentle bütüncül olarak kurgulanmamıştır. Bu odağın oluşturulmasındaki asıl amaç yerleşkenin aktif sahil bandı üzerinden kente entegrasyonunun yapılmasıdır.

Organize tarım odağı: Kıyı bandının doğusu ve batısında bulunan odaklardır. Batıdaki süs bitkileri üretimi ve ticareti yapan tesislerin toplandığı bir alan iken doğudaki alan, Atatürk Bahçe Kültürleri Merkez Araştırma Enstitüsü'nü içine almaktadır.

Yeşil odak: Yatay ve dikey eksenlerin birleştiği, kesiştiği noktada yer almaktadır. Mevcut durumda kentsel merkezin içindeki açık yeşil alanların, gelecek senaryosunda, kentli için yetersiz kalacağı düşünülerek kıyı bandı üzerinde, ihtiyaçları karşılayacak yeşil merkez olarak nitelendirilmiştir. Yürürlükteki imar planında, park alanı olarak ayrılan odak, yetişkin bitkisel öğeleri içinde barındırmaktadır.

Sosyo-kültürel odak:Kentsel odak ile yeşil odağı birbirine bağlarken, Ova mevki beraberinde sosyal ve kültürel donatıları da kıyıya bağlayarak, doğal değerlerin koruma kullanım dengesinin sağlandığı, doğal öğelerin yapısal çevre ile kıyıya entegre edildiği alandır. Böylelikle kent ölçeğinde prestij yaratacak, Yalova Deresi'ni simge konumuna getirecek ve kent içinde erişilebilirlik arttırılacaktır.

Kentsel odak: Yoğun kent örgüsü içinde kalan kentsel odak, feribot iskelesi, marina, şehir içi otobüs durakları, pazaryeri ve alış-veriş merkezi gibi kent içerisinde yoğun kullanılan donatılarla birlikte yüksek yoğunluklu konut alanlarını içine almaktadır. Mevcut durumda bu donatılar,bütüncül olmayan, birbirinden kopuk ve düzensizdir.

Diğer bir gelişim stratejisi olarak, maviden yeşile uzanan bir Termal koridoru öngörülmüştür. Bu koridor Yalova'nın kültür ve turizm değerlerini içermektedir. Aynı zamanda Termal Koridoru ana stratejideki dikey eksendir. Bu entegrasyonla Termal kaplıcaları sayesinde mavi denizden kentin yeşil, kırsal kesimlerine, tarihi ve kültürel değerlerine doğru bir koridor oluşturulması planlanmıştır (Şekil 19). 


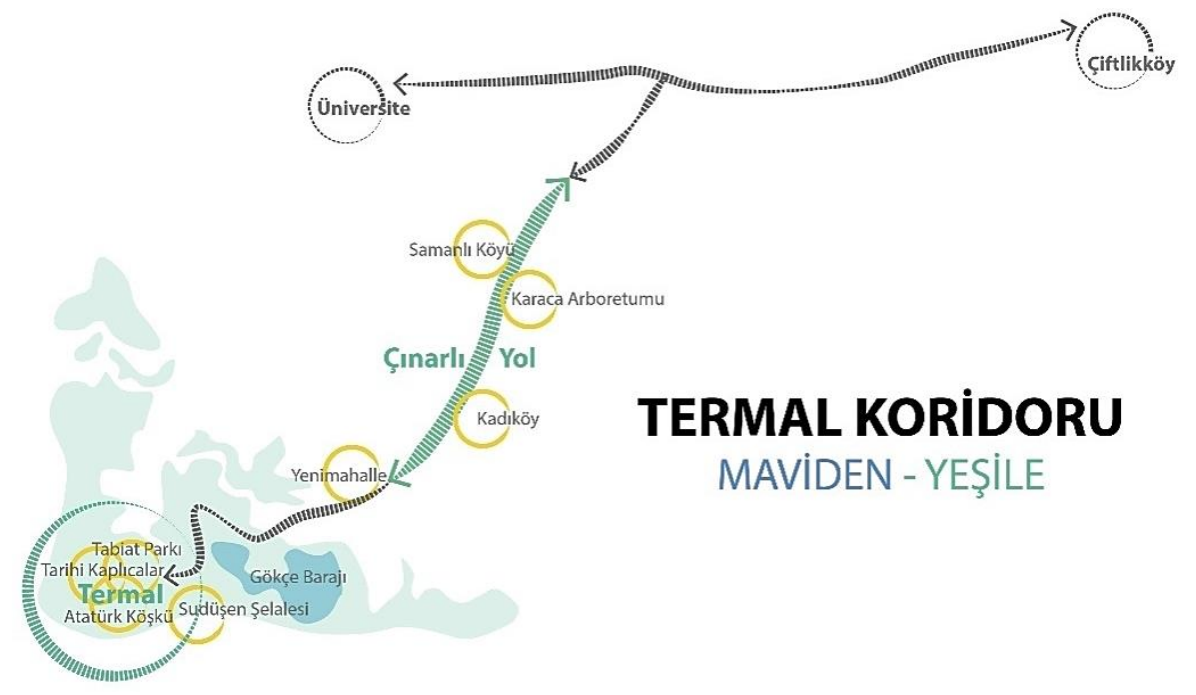

Şekil 19. Termal koridoru, maviden yeşile giden yol

Figure 19. Thermal corridor, the road from blue to green

Sonuç olarak çalışma kapsamında; Yalova merkez ilçe kıyı bandının bütüncül olarak ele alınarak potansiyellerinin değerlendirmesi ve ortaya çıkarılmasıyla sorunlarını çözmeye yönelik hedefler konulmuş ve bu doğrultuda merkez ilçe kıyı bandında mekânsal bazı ıelişim stratejileri önerilmiştir. Bu stratejiler Yalova'nın kıyı kenti imajını güçlendiren, kentin yaşam kalitesini yükselten, kıyı kuşağının kent bütünüyle ilişkide olması gerektiğini vurgulayan, kente sosyal, kültürel, ekonomik ve doğal değer katan mekânsal kazanımları sağlamaya yönelik olmuştur.

\section{ÖZET}

Amaç: Yalova merkez ilçesi kıyı bandının kent ile ilişkisinin kurgulanarak, görsel ve fiziksel kalitenin arttırılması yoluyla sosyal, kültürel ve çevresel anlamda bir odak oluşturulması amaçlanmıştır. Bu amaçla, peyzaj planlama odaklı mekânsal gelişim stratejilerinin geliştirilmesi hedeflenmiştir.

Yöntem ve Bulgular: Çalışma kapsamında kullanılan yöntem; çalışma alanına ilişkin amaç ve kapsamın belirlenmesi, Yalova'ya ilişkin peyzaj değerlerinin belirlenmesi, kent merkezi ile kıyı bandı arasındaki kurgunun saptanması, Swot Analizi, peyzaj planlama odaklı hedef ve alt hedefler temelinde mekânsal gelişim stratejilerinin belirlenmesi olmak üzere beş ana başlık çerçevesinde geliştirilmiştir.

Genel Yorum: Yöntem çerçevesinde elde edilen bulgular kapsamında; kıyı alanının kentten soyutlandığı ve kent ve kıyı arasındaki ilişkinin zayıf olduğu saptanmıştır. Bu kapsamda yine kıyı bandını kentle bütünleştirecek hedef ve stratejiler geliştirilmiştir.

Çalışmanın Önemi ve Etkisi: Yalova merkez ilçe kıyı bandının bütüncül olarak ele alınarak potansiyellerinin değerlendirmesi ve ortaya çıkarılmasıyla sorunlarını çözmeye yönelik hedefler konulmuş ve bu doğrultuda mekânsal bazlı gelişim stratejileri önerilmiştir. Bu stratejiler Yalova'nın kıyı kenti imajını güçlendiren, kentin yaşam kalitesini yükselten, kıyı kuşağının kent bütünüyle ilişkide olması gerektiğini vurgulayan, kente sosyal, kültürel, ekonomik ve doğal değer katan mekânsal kazanımları sağlamaya yönelik olmuştur.

Anahtar Kelimeler: Kentsel peyzaj planlama, mekânsal planlama, kıyı alanı planlaması, Yalova.

\section{ÇIKAR ÇATIŞMA BEYANI}

Yazarlarçalışmakonusundaçıkarçatışmasınınolmadığınıb eyaneder.

\section{ARAŞTIRMACILARIN KATKI ORANI BEYANI}

Yazarlar çalışmaya eşit oranda katkı sağlamış olduklarını beyan eder.

\section{KAYNAKLAR}

Albrechts L (2001). InPursuit of New Approachesto Strategic Spatial Planning. A EuropeanPerspective. International Planning Studies 6(3): 293-310.

AlexandriaWaterfrontSmall Area Plan (2012). City of AlexandriaDepartment of Planning andZonning, USA, https://www.alexandriava.gov/Planning,(Erişim

Tarihi: 22 Eylül 2020)

Anonim (2019). Yalova Nazım İmar Planı. 
TC Yalova Valiliği (2020). Türkiye Cumhuriyeti Yalova Valiliği, Yalova Rehberi. http://www.yalova.gov.tr/yalova-rehberi (Erişim Tarihi: 12 Eylül 2020).

Bender R (1993). Wherethe City MeetstheShore. Waterfronts: A New FrontierforCities on Water, Bruttomesso, R., ed., Venice, s.32-35.

Çevre ve Şehircilik Bakanlığı (2018). Yalova ili 1/50.000 Ölçekli Çevre Düzeni Planı, Plan Açıklama Raporu, Mekânsal Planlama Genel Müdürlüğü. Ankara. 78s.

Duru B(2003). Kıyı Politikası, Kıуı Yönetiminde Bütünleşik Yaklaşımlar ve Ulusal Kıyı Politikası. Ankara: Mülkiyeliler Vakfı Yayınları.

Garipağaoğlu N, Özcan S, Uzun M (2014) ModaCaddebostan (Kadıköy) Arası Kıyı Alanındaki Değişimin İncelenmesi, Marmara Coğrafya Dergisi 0 (29): 60-80.

Hamamcıoğlu C (2005). Kentlerin Suyolu Girişlerinde Geçmişten Günümüze Yaşanan Aşamalar ve Kentsel Tasarım. Planlama, 3: 104-114.

Kalkınma Bakanlığı (2018). Mekânsal Planlama Sistemine İlişkin Değerlendirme Raporu, Yayın no: 2988, 75s.

Kentsel Vizyon Platformu (2011). Yalova Vizyon Planı. http://www.kentselvizyonorg/assets/77 yalova viz yonplani small.pdf (Erişim tarihi: 27 Eylül 2020).
MARKA (2018) Yalova il Yatırım Destek ve Tanıtım Stratejisi ve 2018 Yılı Eylem Planı, Doğu Marmara Kalkınma Ajansı.

http://www.marka.org.tr/Uploads/Files/Yatirim Rap orlari/Yalova\%20Yatırım\%20

Destek\%20ve\%20Tanıtım\%20Stratejisi\%20ve\%20201 8\%20yılı20Eylem\%20Planı\%20(2018).pdf (Erişim Tarihi: 12 Eylül 2020).

Özdemir MA, Bahadır M (2007) Türkiye'de Önemli Bir Seracılık Alanı: Yalova ìli. Coğrafi Bilimler Dergisi 5(1): 17-36

Sanayi ve Teknoloji Bakanlığı (2019) illerin ve Bölgelerin Sosyo-Ekonomik Gelişmişlik Sıralaması Araştırması. Hazırlayanlar: Salih Acar, Mustafa Caner Meydan, Leyla Bilen Kazancık ve Mustafa Işık, Kalkınma Ajansları Genel Müdürlüğü Yayını, Sayı: 3, Araştırma Raporu Sayı: 3, Ankara.

Şolt HBH (2018). Kentlilerin Kıуı Alanı Düzenlemesine Bakışı: Alaplı Örneği. Aksaray Üniversitesi İktisadi ve İdari Bilimler Fakültesi Dergisi 10 (2): 55-62.

TÜik (2019). TC Başbakanlık Tüik-2019 Yalova Nüfus Bilgileri. http://www.tuik.gov.tr (Erişim Tarihi: 12 Eylül 2020)

Yalova II Kültür ve Turizm Müdürlüğü (2020). https://yalova.ktb.gov.tr/TR-128112/ulasim-nasilgidilir.html (Erişim tarihi: 30 Eylül 2020) 